\title{
DECAY OF THE HEARTWOOD IN LOWER AND UPPER TRUNK OF PINUS SYLVESTRIS BY PORODAEDALEA PINI
}

\author{
Wojciech Szewczyk ${ }^{\bowtie}$ \\ Department of Forest Pathology, Poznań University of Life Sciences \\ Wojska Polskiego 71C, 60-625 Poznań, Poland
}

\begin{abstract}
This article presents the results of research on decay of Scots pine heartwood in the lower and upper parts of the trunk by Porodaedalea pini. The rates of decay of wood in the lower and upper parts of the trunk were similar. The isolate of $P$. pini had a significant effect on rate of wood decay.
\end{abstract}

Key words: Porodaedalea pini, decay, heartwood, Scots pine

\section{INTRODUCTION}

Porodaedalea pini (Brot.) Murrill. (syn. Phellinus pini (Brot.) Bondartsev \& Singer) is a fungal plant pathogen that causes disease of the coniferous tree commonly known as "red ring rot" or "white speck". It infects a wide range of trees, including jack pine, lodgepole pine, Scots pine, Sitka and white spruce, Douglas-fir, balsam and true fir, western hemlock, and tamarack. The disease occurs in monotypic and mixed stands in Europe, including Poland, and in northern Asia and North America. The disease is important in older stands ( $>20$ years old).

The fungus decays tree trunks, rendering them useless for lumber (harvesting). It attacks both heartwood and sapwood and causes white pocket trunk rot. Symptoms of colonization include shelf-shaped conks (sporophores) protruding from the trunks of trees. The decay may extend approximately $1.5 \mathrm{~m}$ above and $1 \mathrm{~m}$ below a conk. Decay tends to occur in the lower part of the trunk, but may also develop in large roots. The white pockets are formed in advanced stages of decay, usually in places where the conks develop. Their formation results from degradation of lignin. They are mostly hollow (delignified) and contain white residual cellulose. Basidiospores produced on the conks are blown by the wind and infect other trees. Once they land on a suitable small wound or twig stub, the spores may germinate and the mycelia grow into the inner wood. Branches are susceptible to attack by the fungus from the time they have dead wood until they have been dead for about 20 years. The proportion of infected pine trees increases with the age of the stand.

In Poland, in 100- and 160-year-old stands, about $15-35 \%$ and $100 \%$ of all pine trees respectively can be infected (Mańka, 2005). The extent of rot in the trunk increases with age; growth rate of the rot in old trees may exceed the growth rate of uncolonized wood (Mańka, 2005). Porodaedalea pini produces cellulase with a higher level of activity than that of ligninolytic enzymes, and decomposes lignin at a higher rate than carbohydrates (Yoshizawa et al., 1992).

Porodaedalea pini is one of the most common and destructive heart-rot pathogens. The fungus usually destroys the lower part of the trunks. which is the most valuable from the commercial point of view (Mańka,

অszew@up.poznan.pl 
2011). Each year $8 \%$ of Scots pine wood produced in Poland is colonized and decayed by the fungus (Mańka, 2005). Apart from the economic impact. red ring rot decay leads to mechanical failure of live trees, and these may cause a potential hazard in recreational or public areas. As an important forest disturbance agent it plays a key role in habitat formation for several forest animals.

Formal management of this disease is limited, and the disease is controlled primarily by cultural practices. Where timber management is the focus, infected trees should be removed. Reduction in rotation age should be considered if decay is frequent to minimize losses. Injuries to healthy trees should be avoided during logging to prevent new infections.

The aim of the study was to evaluate the rate of decay of the heartwood in the lower and upper parts of the trunk of Scots pine by P. pini.

\section{MATERIAL AND METHODS}

Ten specimens of $P$. pini from living $P$. sylvestris L. trees were included in the study (Table 1). Their sporophores were collected in forests of north-western Poland (Durowo, Góra Śląska, Grodzisk, Wełna, Rudka and Zielonka Forest Districts) in 2008-2010. Distances between locations surveyed ranged between 20 and $600 \mathrm{~km}$. Specimens were originally identified according to host preferences and morphological characters of sporophores and basidiospores. Their morphological identification was confirmed by the sequencing of the ITS1/2 rDNA (Szewczyk et al., 2014).

Axenic, dikaryotic $(n+n)$ cultures were obtained from the fresh sporophore context material taken from above the hymenium with a sterile scalpel and plated on Goldfarb's selective medium (malt agar - $15 \mathrm{~g} / \mathrm{l}$, prochloraz - $1 \mathrm{mg} / \mathrm{l}$, benomyl - $1 \mathrm{mg} / \mathrm{l}$, thiobendazole $-1 \mathrm{mg} / \mathrm{l}$, streptomycin - $1 \mathrm{mg} / \mathrm{l}$, rose Bengal - $1 \mathrm{mg} / \mathrm{l}$ ). After $7-14$ days of incubation at $24^{\circ} \mathrm{C}$ in darkness, fungi were transferred to $1.5 \%$ malt medium (malt extract $15 \mathrm{~g} / \mathrm{l}$, peptone $5 \mathrm{~g} / \mathrm{l}$ agar Difco $15 \mathrm{~g} / \mathrm{l}$ ) and maintained at $4^{\circ} \mathrm{C}$ in darkness.

Wood decay tests were conducted on the heartwood of Scots pine. Sound heartwood, without damage or knots, was obtained from the lower part (the butt) and the upper part (the 9th $\mathrm{m}$ ) of the trunk, from two 110-year-old Scots pines, in Durowo Forest District with low risk of $P$. pini infection. Research procedures followed the PN-EN 350-1 standard (PN-EN 350-1, 2000; Sierota et al., 2016; Szewczyk, 2015). Wood blocks $(1.5 \times 2.5 \times 5.0 \mathrm{~cm})$ were dried at $105^{\circ} \mathrm{C}$ for $72 \mathrm{~h}$ to constant weight, weighed to an accuracy of $0.001 \mathrm{~g}$ and sterilized at $121^{\circ} \mathrm{C}$ for $30 \mathrm{~min}$. Blocks of comparable weight were selected for analysis. Sterilized wood blocks were wetted with distilled water for over $1 \mathrm{~h}$ (until reaching 35-40\% moisture level). Six blocks were placed in Kolle flasks on $35 \mathrm{ml}$ of sterile $\left(121^{\circ} \mathrm{C}\right.$ for $\left.30 \mathrm{~min}\right)$ malt extract agar (malt extract Difco Sparks MD USA $20 \mathrm{~g} / \mathrm{l}$. agar Difco $15 \mathrm{~g} / \mathrm{l}$ ) with a growing. 7-day-old. single isolate of $P$. pini. Blocks were taken out after 12 weeks of incubation at $21^{\circ} \mathrm{C}$, cleaned of surface mycelium, weighed, dried preliminarily, and dried at $105^{\circ} \mathrm{C}$ for $72 \mathrm{~h}$ to constant weight before being weighed again. The loss of dry weight and moisture content of the blocks were calculated.

\section{Statistical analysis}

The effect of wood origin (from the lower or upper part of the trunk) and of $P$. pini isolate on the decay rate (shown by loss of weight) was analysed with Duncan's new multiple range test (MRT) at a significance level $\alpha=0.05$ (Kozak et al., 2013). The evaluation of $P$. pini isolates was performed on the mean values for loss of weight in the lower and upper parts of the trunk.

\section{RESULTS AND DISCUSSION}

All P. pini strains studied were able to degrade the heartwood of Scots pine, albeit to varying degrees. After 12 weeks at $21^{\circ} \mathrm{C}$ the loss of weight of Scots pine heartwood was (1) less $(7.78-11.12 \%)$ from the lower part of the trunk and (2) greater (10.32-14.85\%) from the upper part of the trunk (Table 1). This effect seemed to result from the different density of wood along the trunk of Scots pine. Lower density in the upper part seems to favour the spread and colonization by $P$. pini mycelium and enhance wood decay (Repola, 2006; Szczepkowski, 2010; Zarzycki and Andres, 2010). This is often manifested by the longer and shorter decay columns above the upper and lower P. pini sporophores. respectively (Mańka, 2005). However. taking the statistical analyses into account. the rates of decay of heartwood were not significantly different in the lower and upper parts of the trunk 
Table 1. Results of the decay test

Tabela 1. Wyniki doświadczenia nad rozkładem drewna

\begin{tabular}{|c|c|c|c|c|c|}
\hline \multirow{2}{*}{$\begin{array}{l}\text { Origin of } P \text {. pini } \\
\text { Pochodzenie } \\
\text { izolatów P. pini }\end{array}$} & \multicolumn{2}{|c|}{$\begin{array}{l}\text { Mean loss of wood weight, } \% \\
\text { Średnia utrata masy drewna, } \%\end{array}$} & \multicolumn{3}{|c|}{$\begin{array}{l}\text { Homogenous subsets compared by Duncan's } \\
\text { new multiple range test } \\
\text { Grupy jednorodne utworzone na podstawie } \\
\text { wielokrotnego testu rozstępu Duncana }\end{array}$} \\
\hline & $\begin{array}{l}\text { in the lower part of the trunk } \\
\text { w dolnej części strzały }\end{array}$ & $\begin{array}{l}\text { in the upper part of the trunk } \\
\text { w górnej części strzały }\end{array}$ & 1 & 2 & 3 \\
\hline Grodzisk & 9.34 & 10.51 & & & $*$ \\
\hline Durowo 1 & 7.78 & 10.97 & & $*$ & $*$ \\
\hline Durowo 3 & 8.32 & 10.32 & & $*$ & $*$ \\
\hline Durowo 4 & 8.23 & 11.25 & $*$ & $*$ & $*$ \\
\hline Durowo $6 / 2$ & 10.28 & 11.13 & $*$ & $*$ & $*$ \\
\hline Wełna 2 & 8.98 & 13.61 & $*$ & $*$ & \\
\hline Rudka & 10.83 & 13.24 & * & $*$ & \\
\hline Góra Śląska & 9.28 & 14.21 & * & & \\
\hline Zielonka & 11.12 & 12.23 & $*$ & & \\
\hline Durowo 12 & 9.98 & 14.85 & $*$ & & \\
\hline
\end{tabular}

*Asterisks show statistically similar degradation rates in each subset column.

*Gwiazdki w kolumnie wskazują statystycznie podobne wartości utraty masy.

(Duncan's test at $\alpha=0.05$ ). This suggests no major effect of physical and chemical properties of Scots pine wood on degradation rate by $P$. pini.

The isolates of $P$. pini tested were grouped into three homogeneous subsets $(1,2,3$; Table 1$)$ that included isolates with similar efficacy. All three subsets included isolates originating from different locations. which suggests that there was no effect of geographical distribution of $P$. pini on its degradation properties.

\section{REFERENCES}

Kozak, M., Bocianowski, J., Rybiński, W. (2013). Note on the use of coefficient of variation for data from agricultural factorial experiments. Bulgarian J. Agric. Sci., 19, 644-646.

Mańka, K. (2005). Fitopatologia leśna [Forest pathology]. Warszawa: PWRiL [in Polish].

Mańka, M. (2011). Choroby drzew leśnych [Diseases of forest trees]. Warszawa: PWRiL [in Polish].

PN-EN 350-1 (2000). Trwałość drewna i materiałów drewnopochodnych - Naturalna trwałość drewna litego - Wytyczne dotyczące zasad badania i klasyfikacji naturalnej trwałości drewna [Durability of wood and wood-based products - Natural durability of solid wood - Guide to the principles of testing and classification of the natural durability of wood]. Warszawa: PKNiM [in Polish with English summary].

Repola, J. (2006). Models for vertical wood density of Scots pine, Norway spruce and birch stems, and their application to determine average wood density. Silva Fenn., 40, 673-685.

Sierota, Z., Wrzosek, M., Małecka, M., Zółciak, A. (2016). Decay indices for evaluating wood decomposition activity. Biocontr. Sci. Techn., 26 (2), 163-173. DOI: 10.1080/09583157.2015.1085000

Szczepkowski, A. (2010). Odporność drewna dębu szypułkowego (Quercus robur L.), z drzew o różnym stanie zdrowotnym, na rozkład powodowany przez grzyby [Resistance to decay caused by fungi of common oak (Quercus robur L.) wood from trees of different health status]. For. Res. Pap., 71(2), 125-133 [in Polish].

Szewczyk, W. (2008). Occurrence of Phellinus pini (Brot) Bondarstser et Singer in selected Scots pine stands of Northern Poland. Acta Sci. Pol., Silv. Colendar. Rat. Ind. Lignar. 7, 23-26. 
Szewczyk, W., Kwaśna, H., Behnke-Borowczyk, J., Baranowska-Wasilewska, M. (2014). Phylogenetic relationships among Porodaedalea pini from Poland and related Porodaedalea species. Open Life Sci., 9(6), 614-627.

Szewczyk, W. (2015). Wood decomposition to Porodaedalea pini from different regions of Poland. Drewno, 58, $127-134$

Yoshizawa, N., Itoh, N., Sunagawa, M., Yokota, S., Idei, T. (1992). Comparative and enzyme activities during wood decay by white rot fungi with selective lignin degrading abilities. Bull. Utsunomiya Univ. For., 28, 97e110.
Zarzycki, P., Andres, B. (2010). Laboratoryjna ocena możliwości wykorzystania wybranych związków fenolowych naturalnie występujących $\mathrm{w}$ drewnie do zabezpieczania drewna lipowego przed rozkładem przez grzyby [Laboratory assessment of usability of selected phenolic compounds naturally existing in wood for protection of lime wood against decay caused by fungi]. Sylwan, 154, 515-523 [in Polish].

\section{ROZKŁAD DREWNA TWARDZIELOWEGO SOSNY ZWYCZAJNEJ DOLNEJ I GÓRNEJ CZĘŚCI STRZAŁY POWODOWANY PRZEZ PORODAEDALEA PINI}

\section{ABSTRAKT}

Artykuł zawiera wyniki badań nad rozkładem drewna twardzielowego sosny z dolnej i górnej części strzały przez Porodaedalea pini. W wyniku przeprowadzonych badań stwierdzono, że drewno twardzielowe z dolnej i górnej części strzały jest rozkładane w tym samym tempie. Stwierdzono, że rozkład drewna był determinowany przez izolat grzyba.

Słowa kluczowe: huba sosny, zgnilizna biała jamkowata, zgnilizna drewna twardzielowego 